\title{
CATALYTIC ACTIVITY OF SELECTED SERUM ENZYMES IN EXPERIMENTAL SARCOCYSTOSIS IN CALVES
}

\author{
M. NEVOLE, ${ }^{1}$ L. MALOTA ${ }^{2}$ and B. KOUDELA ${ }^{3}$ \\ Department of Pathological Morphology and Parasitology, ${ }^{1}$ Department of Chemistry, Physics \\ and Biochemistry, ${ }^{2}$ University of Veterinary Science \\ 61242 Brno
}

Institute of Parasitology, Czechoslovak Academy of Sciences, Ceské Budějovice ${ }^{3}$

Received December 20, 1984

\begin{abstract}
Nevole M., L. Malota, B. Koudela: Catalytic Activities of Selected Serum Enzymes in Experimental Sarcocystosis in Calves. Acta vet. Brno, 55, 1986: 81 - 84.

Activities of blood serum enzymes, creatine kinase (CPK, EC 2.7.3.2.), lactate dehydrogenase (LDH, EC 1.1.1.27), and gamma-glutamyl transferase (GGT, EC 2.3.2.1.) were investigated in seven calves during the course of experimental sarcocystosis. In calves infected orally with $S$. cruzi sarcocysts these enzyme activities differed from those found in control animals. The activities of CPK and GGT were elevated from the third week after infection, and reached a maximum in weeks 8 and 9 of the disease. Serum LDH activity was elevated from the 7 th week with a maximum in the 9th week post infection. Likewise the proportion of $\mathrm{LDH}$ isoenzyme 1 showed an increase from the 7 th week reaching a maximum in the 9th week. The increased catalytic activities of blood serum enzymes correlated well with the course of the disease in calves.
\end{abstract}

Experimental infection, calves, blood serum enzymes, disc electrophoresis.

Sarcocystosis is a disease caused by two-host coccidia of the genus Sarcocystis. Cattle are the intermediate hosts of three Sarcocystis species, namely, S. cruzi, S. hirsuta and S. hominis. Of these, $S$. cruzi is the most pathogenic one for cattle. Less information is available on the two other species (Černá 1983). Parasitizing sarcocysts cause a number of clinical symptoms in cattle such as anaemia, haemorrhagiae, diarrhoea, anorexia, loss of body mass, catarrhal enteritis, and gross lesions such as degenerative hepatitis, necrotizing myocarditis, hyperplasia of the lymphoreticular system, sometimes even haemorrhagic lymphadenitis. These symptoms may lead to death in young calves (Nevole et al. 1985). The occurrence and severity of the above-mentioned symptoms in infected animals correlates with the developmental cycle of the parasite depending on the numbers and localization of the meronts (Dubey 1983).

The developmental cycle of the parasite in the host organism is relatively well known and manifests itself e.g. by changes in catalytic activities of organ specific enzymes such as serum LDH and GOT (Frelier et al. 1977; Dubey et al. 1981). In calves, the following values of serum enzymes have been described as physiological by Jagos and Bouda (1981): gamma-glutamyltransferase up to $0.58 \mu \mathrm{mol} / \mathrm{l}$, lactate dehydrogenase 11.12 to $16.73 \mu \mathrm{mol} / \mathrm{l}$, creatine kinase 0.0 to $0.668 \mu \mathrm{mol} / 1$.

The changes in catalytic activities of serum enzymes reflect the pathophysiological processes in the organism; in this case during the asexual phase of sporocyst multiplication. Therefore the aim of the present experiment was to follow the course of changes in catalytic activities of serum CPK, LDH and GGT in experimentally infected calves.

\section{Materials and Methods}

Seven Red Danish calves aged 1 month were used in the experiment. They were housed in one pen and for 4 weeks fed a milk diet later supplemented by hay and a feed mixture for calves. 
Sporocysts of $S$. cruzi (S. bovicanis) were isolated from faeces of dingo dogs (ZOO in Ústí nad Labem). The faeces were processed by the flotation method using Shearton sugar solution. From each test tube $1 \mathrm{ml}$ of supernatant with sporocysts was removed. After washing out the flotation solution the sporocysts were resuspended in physiological saline and counted. The calves were inoculated orally as follows: calf No. 1 was given 500000 sporocysts, calf. No. 2 1 million sporocysts, calves No. 4 and 6 were inoculated with 250000 sporocysts, and calves No. 3,5 and 7 served as controls.

Blood samples were collected from $v$. jugularis externa in all calves at weekly intervals. Catalytic activities of the serum enzymes were determined using the commercial Bio - La tests (Lachema Brno). The following enzymes were studied: LDH, CPK and GGT. The enzyme activities were measured using a Varian-Techtron UV-VIS, model 634 apparatus. Isoenzymes LDH were determined by disc electrophoresis in polyacrylamide gel. The gel was pipetted into glass tubes $(0.5 \mathrm{~cm}$ in diameter, $8 \mathrm{~cm}$ length). Separation was carried out in $7 \%$ gel in the electrophoretis chamber filled with TRIS -glycerine buffer, $\mathrm{pH} 8.4$ at constant current of $5 \mathrm{~mA}$ per gel tube, for 120 minutes. The development of the tubes was carried out using a mixture of $6.75 \mathrm{ml}$ lactic acid (pH 9.2), $4.5 \mathrm{ml} \mathrm{NAD}{ }^{+}, 12.5 \mathrm{ml}$ tetrazolium blue, and $1.25 \mathrm{ml}$ fenasin-methosulphate. The substances were dissolved in deionized water. The developing time was 20 minutes at $37^{\circ} \mathrm{C}$ in a thermostat (Hylgaard - Jensen 1971). Densitometric evaluation of the gel was carried out with a Beckmann densitometer, model CDS-200.

\section{Results}

Catalytic activity of CPK (specific muscle enzyme) began to increase in infected calves as soon as 3 weeks post infection with a maximum in weeks 8 and 9 , whereas in control calves its activity was considerably lower (Fig. 1).

Catalytic activity of GGT increased during the week 3 post infection, with a maximum in the week 9. Interestingly, in calves infected with the lowest dosis of 250000 sporocysts, the catalytic activity of this liver enzyme was increased as soon as one week after infection (Fig. 2).

LDH showed an increased catalytic activity only from the 7th week post infection with a maximum in the 9th week, while essentially no change was found in the control animals (Fig. 3). In the infected calves, also a change in the spectrum of LDH iso-

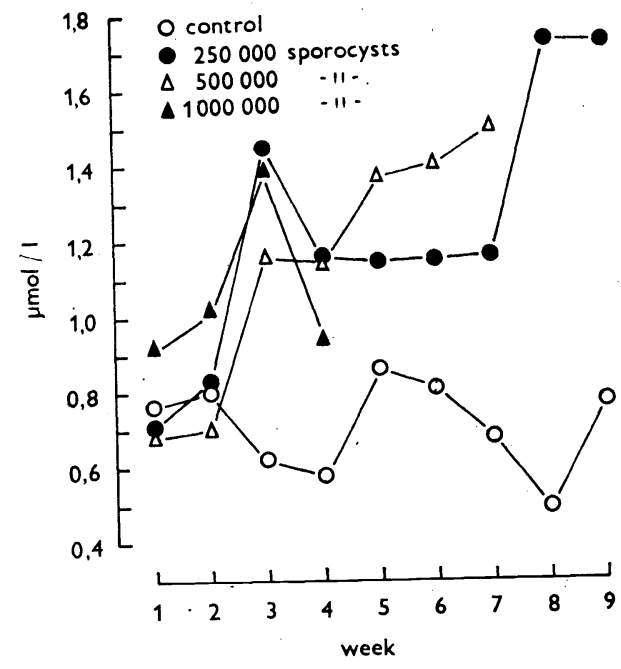

Fig. 1

Catalytic activity of CPK

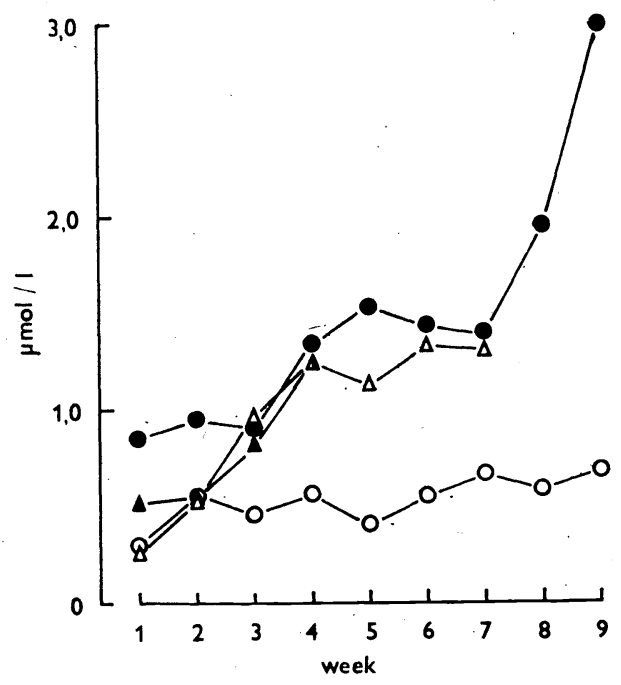

Fig. 2

Catalytic activity of GGT 


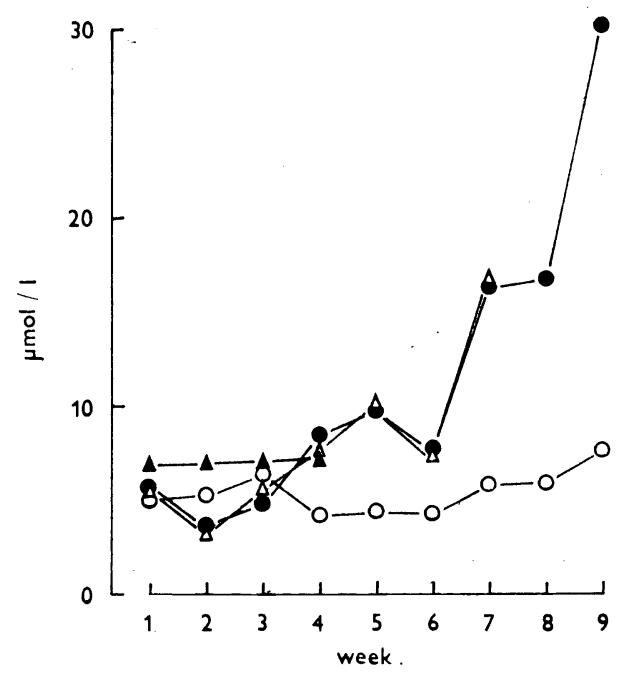

Fig. 3

Catalytic activity of LDH

enzymes was observed. From the 7th week, an increase in isoenzyme 1 activity was observed with a maximum in the 9 th week.

In the course of the experiment, calf No. 2 died 4 weeks post infection, calf No. 1 died 8 weeks post infection. Necropsy findings in these calves are discussed in another paper (Nevole et al. 1985).

\section{Discussion}

Clinical symptoms accompanying sarcocystosis have been repeatedly described (Dubey et al. 1981; Dubey et al. 1983; Jungmann et al. 1977; Frelier et al. 1977). Catalytic activities of serum enzymes were investigated by several of these and by other authors (e.g. Prasse and Fayer 1981). The onset and intensity of clinical symptoms is dependent on the numbers of meronts produced after infection.

In our experiment, however, there was no direct relationship between the dose of inoculated sporocysts and the increased enzyme activities. These seem to have been related to the development of the parasite in the intermediate host's body. After ingestion by the host the sporocysts disintegrate and the sporozoites penetrate through the intestinal wall into the bloodstream. They invade the endothelial cells of capillaries, especially in the kidneys, lymph nodes, spleen, liver, myocardium, brain and other organs. Here, within 14 to 30 days they multiplicate by synchronous endopolygony, and the young merozoites are transported by the bloodstream into skeletal and heart musculature. Metrocytes derived from splitting up of merozoites become sarcocysts that may be found in musculature about 6 weeks after infection. Development of these muscular cysts is accompanied by degenerative changes and rupture of muscle fibers, sometimes even myositis develops. It is this process that results in increased catalytic activities of the serum enzymes involved, and of LDH isoenzymes. In our experiment, degenerative changes of the liver tissue accompanied by elevated GGT activity occurred as soon as in the third week post infection. The pattern of changes in CPK activity during the first post infection weeks was in good agreement with the results of Prasse and Fayer (1981), Jungmann et al. (1977) and Dubey et al. (1981). Catalytic activity of LDH remained unchanged until the 7th week after infection. The changes in the LDH isoenzyme spectrum with an increasing liver fraction is indicative of liver damage as is the sharp increase in the GGT activity.

It is possible that sarcotoxin, too, participates in damage of liver cells. The effects of sarcotoxin have been not fully elucidated as yet (Schmidt 1967). Regarding the fact that liver sinusoids possess no basal membranes, its presence in liver parenchyma may enhance the enzyme transport from cells into the blood. Our results differ somewhat from those of other authors who did not find changes in enzyme activities in this phase of the disease (i.e. between days 40 to 63 post infection). Elevated 
catalytic activity of alanine amino transferase between days 24 and 63 post infection was found only by Prasse and Fayer (1981).

\section{Katalytická aktivita enzymů u experimentální sarkocystózy telat}

U sedmi telat byla studována katalytická aktivita sérové kreatinfosfokinásy (CPK, EC 2.7.3.2), laktátdehydrogenásy (LDH, EC 1.1.1.27) a gama-glutamyltransferásy (GGT, EC 2.3.2.1) v prủběhu experimentální sarkocystózy.

U čtyř invadovaných telat byly prokázány rozdílné hodnoty oproti telatům kontrolním. Aktivita CPK a GGT stoupala ve třetím týdnu po invazi a dosáhla maxima $\mathrm{v}$ osmém a devátém týdnu onemocnění. Aktivita LDH se změnila $\mathrm{v}$ průběhu sedmého týdne s maximem v devátém týdnu po invazi. Podíl isoenzymu č. 1 narůstal od sedmého týdne $\mathrm{s}$ nejvy̌šíi aktivitou $\mathrm{v}$ týdnu devátém. Zvýšení katalytické aktivity sérových enzymů odpovídá patogenesi tohoto onemocnění.

\section{Каталитическая активность энзимов у экспериментального саркоцистоза телят}

С семью телятами проводились иоследования каталитической активности сывороточной креатинюфосфокиназы (СРК, ЕС 2.7.3.2), лактатдегидрогеназы (LDH, EC 1.1.1.27) и гамма-глютамилтранюферазы (GGT, ЕС 2.3.2.1). В ходе экспериментального саркоцистола у четырех телят были установлены разные величины активности энзимов по сравнению с контрольными телятами. Активность КФК и ГГТ повышалась на третьей неделе после инвазии, достигая максимума на восьмой, девятой неделе заболевания. Активность ЛДГ менялась в течение седьмой недели с максимумом на девятой неделе после инвазии. Доля изоэнзима № 1 нарастала с седьмой недели с максимальной активностью на девятой неделе. Увеличение каталитической активности сывороточных энзимов соответствует патогенезу данного заболевания.

\section{References}

ČERNÁ, Ž.: Kokcidie některých domácích a užitkových zviřat a kokcidie člověka. ACADEMIA, Praha, 1983: 160.

DUBEY, J. P.: Clinical Sarcocystosis in Calves Fed Sarcocystis hirsuta Sporocysts from Cats. Vet. Pathol., 1983: 90-98.

DUBEY, J. P. - WEISBRODE, S. E. - SPEER, C. A. - SCHARMA, S. P.: Sarcocystosis in Goats: Clinical Signs and Pathologic and Hematologic Findings. JAVMA, 178, No 7., 1981: 683-698.

FRELIER, P. - MAYHEW, I. G. - FAYER, R. - LUNDE, M. N.: Sarcocystosis: A Clinical Outbreac in Dairy Calves. SCIENCE, 195, 1977: $1341-1342$.

HYLDGAARD-JENSEN, J. F.: Lactate Dehydrogenase in Pigs. Munksgaard, Copenhagen, 1971: 220.

JAGOŠ, P. - BOUDA, J.: Základní biochemické a hematologické hodnoty u domácích zviŕat a nové způsoby vyjadřování výsledkủ laboratorních vyšetření. Klub přátel VŠV, Brno, 1981: 29.

JUNGMANN, R. - BERGMANN, V. - HIEPE, T. - NEDJARI, T.: Untersuchungen zur septikämisch verlaufenden experimentellen Sarcocystis bovicanis - Infection des Rindes. Monatshefte für Veterinärmedizin, 23, 1977: 885-889.

NEVOLE, M. - KOUDELA, B. - LUKESOVÁ, D. - SVOBODOVÁ, V.: Vývoj sarkocystózy u experimentálně invadovaných telat. Vet. med. Praha, 1, 1985: 29-35.

PRASSE, K. W. - FAYER, R.: Hematology of Experimental Acute Sarcocystis bovicanis Infection in Calves. Vet. Pathol., 18, 1981: 358-367.

SCHMIDT, E.: Isoenzymes of malic dehydrogenase, glutamic oxalacetic transaminase and lactic dehydrogenase in serum and diseases of the liver. Clin. chim. Acta, 15, 1967: 283 - 289. 